\title{
Superficial Basal Cell Carcinoma
}

National Cancer Institute

\section{Source}

National Cancer Institute. Superficial Basal Cell Carcinoma. NCI Thesaurus. Code C62284.

A variant of basal cell carcinoma of the skin presenting as erythematous, often multiple patches. Morphologically, it is characterized by the presence of superficial lobules of basaloid cells projecting into the dermis. The basaloid cell lobules are surrounded by myxoid stroma and are usually confined to the papillary dermis. 